DOI https://doi.org/10.30525/978-9934-26-114-5-72

\title{
РІВЕНЬ ОПЛАТИ ПРАЦ ОСВІТЯН: КОНСТРУКТИВНИЙ ЧИ ДЕСТРУКТИВНИЙ ФАКТОР ТРАНСФОРМАЦІЇ СИСТЕМИ ВИЩОЇ ОСВІТИ В УКРАЇНІ?
}

\author{
Шевченко І. Ю. \\ доктор економічних наук, дочент, \\ декан факультету управління та бізнесу \\ Харківський національний автомобільно-дорожній університет \\ м. Харків, Україна
}

Багатостраждальна система вищої освіти України вже тривалий час потерпає від низки складних i комплексних проблем. У попередніх дослідженнях [1-2] було виявлено системні проблеми, з якими повсякчасно стикається система вищої освіти України, серед яких чільне місце займають скорочення контингенту здобувачів вищої освіти та нестача фінансування. Зрозуміло, що зазначені процеси не могли не позначитися негативним чином на ресурсному забезпеченні закладів вищої освіти.

Попри те, в суспільстві домінує стійке переконання, що в освітній діяльності не так важливе матеріально-технічне забезпечення, бо основна цінність освітньої системи - це викладач. 3 цим також важко не погодитися, адже педагогічна майстерність викладача більшою мірою визначає результат навчання, ніж, наприклад, наявність більш сучасних комп'ютерів чи популярних сьогодні фліп-чартів. Але нестача фінансових ресурсів незмінно призводить до зменшення фонду оплати праці та, відповідно, до необхідності скорочення штатного розпису. Зрозуміло, що кожен керівник закладу освіти буде «боротися до кінця» за свої кадри та буде прагнути уникнути звільнення викладачів. Але цей шлях приведе до того, що викладачі не будуть мати повної зайнятості за основним місцем роботи та будуть вимушені шукати заробітків за іншими видами діяльності, тим самим відволікаючись від викладання. А це призведе до зниження якості освітніх послуг.

Часто можна почути думку, що постійна робота в умовах скорочення штатів має, навпаки, стимулювати викладача до найбільш якісного виконання своїх обов'язки задля того, щоб довести свою «необхідність» у колективі. Але, наприклад, у системі вищої освіти існує ряд показників ефективності діяльності науково-педагогічного працівника (до прикладу, наукові публікації, видання підручників, навчальних посібників, монографій тощо), які потребують від нього не 
лише інтелектуальних вкладень, а й матеріальних витрат. Тут вже постає питання «економічної ефективності»: скільки буде складати реальна заробітна плата науково-педагогічного працівника за вирахуванням витрат на підтримку своєї кваліфікації та високого рейтингового місця? Можна багато говорити про те, що викладач - це покликання, а гроші треба заробляти в бізнесових видах діяльності... Але ж викладач - це така ж жива людина, яка має такі ж потреби, як і інші люди, - у харчуванні, речах, житлі, дозвіллі, відпочинку, забезпеченні матеріального благополуччя сім'ї тощо.

Ситуація, що склалася, деякими практиками сприймається навіть позитивно: мовляв, «виживуть найсильніші». Тобто скорочення кількості науково-педагогічних працівників - це ніяка не криза, а еволюція. У попередньому дослідженні [3] ця смілива теза розглядалася та було доведено, що не слід так однозначно сприймати кадрові процеси у системі вищої освіти України. Не продовження контракту з викладачами старшого віку 3 огляду на їх традиційно нижчі позиції у рейтингу науково-педагогічних працівників не слід сприймати лише як «справедливе рішення за результатами рейтингування». Сама ідея «залишити найсильніших» є життєздатною лише в короткостроковому чи середньостроковому періоді: по-перше, будь-який соціум потребує диференціації його учасників, тобто з часом серед «найсильніших» будуть виділятися «слабші», роль яких раніше, як правило, виконували викладачі старшого віку; по-друге, як відомо, з часом ефективність працівників зменшується - зазвичай цьому сприяють або впевненість у своєму місці в колективі, або моральна втома, або навіть «вигоряння працівника». Відповідно, така система потребує «вливання свіжої крові» - появи молодих фахівців, які будуть проходити становлення та 3 часом почнуть конкурувати 3 так званими «найсильнішими», перемагати у конкурентній боротьбі та в перспективі їх замінять. Наче в теорії все виглядає непогано.

Але тут в ладно вибудувану теорію втручається такий фактор як «рівень оплати праці викладачів». У системі вищої освіти України нарахування заробітної плати науково-педагогічних працівників здійснюється зі значним акцентом на надбавки, основні з яких - за вислугу років (стаж), за науковий ступінь, за вчене звання. Згідно Закону України «Про вищу освіту» «науково-педагогічним, науковим i педагогічним працівникам закладів вищої освіти встановлюються доплати за науковий ступінь доктора філософії та доктора наук у розмірах відповідно 15 та 25 відсотків посадового окладу, а також за вчене звання доцента і старшого дослідника - 25 відсотків посадового окладу, професора - 33 відсотки посадового окладу» [4]. Згідно Закону України «Про освіту» «педагогічним і науково-педагогічним працівни- 
кам встановлюються щомісячні надбавки за вислугу років у розмірах: понад три роки - 10 відсотків; понад 10 років - 20 відсотків; понад 20 років - 30 відсотків посадового окладу» [5]. Тобто молодий фахівець, який тільки починає свій шлях у науково-педагогічній діяльності, за «другою частиною» заробітної плати буде поступатися своїм більш досвідченим колегам з науковими ступенями та вченими званнями від 50 до 88\% посадового окладу. До цього ж слід додати, що розміри посадових окладів науково-педагогічних працівників також значно різняться. Свій професійний шлях у закладі вищої освіти в Україні молоді фахівці, як правило, починають 3 посад «викладач-стажист», «асистент», «викладач». Згідно [6] станом на 1 січня 2021 року посадовий оклад викладача-стажиста складав 7646,79 грн., асистента чи викладача - 8268,39 грн. Тоді як посадовий оклад, наприклад, доцента у той же час складав 10135,41 грн. Тобто це різниця на 22,58-32,54\%. На посаді доцента, як правило, знаходяться особи, які мають науковий ступінь кандидата наук або доктора філософії. Навчання в аспірантурі наразі триває 4 роки. Для займання посади доцента потрібно мати стаж науково-педагогічної діяльності не менше 5 років. Тобто, якщо умовний доцент нещодавно захистив дисертацію, почав працювати на посаді доцента та ще не має вченого звання доцента, то його заробітна плата вже буде більшою на $65,68 \%$ за заробітну плату молодого фахівця, який почав працювати на посаді викладача-стажиста, та більшою на $53,23 \%$ за заробітну плату молодого фахівця, який почав працювати на посаді асистента чи викладача.

Проте, проблема залучення молодих фахівців на працю до закладів вищої освіти в Україні полягає не лише в суттєвій диференціації у порівнянні з колегами, що займають вищі посади науково-педагогічних працівників, а й у традиційно низькій заробітній платі викладачів. Так, указаний вище розмір посадового окладу викладача-стажиста лише на $27,45 \%$ вищий за розмір мінімальної заробітної плати в Україні у 2021 році (6000 грн. [7]), розмір посадового окладу асистента чи викладача на $37,81 \%$ вищий за розмір мінімальної заробітної плати в Україні у 2021 році. 3 іншого боку, розмір посадового окладу викладача-стажиста становить 3,37 розміру прожиткового мінімуму для працездатних осіб в Україні у 2021 році (2270 грн. [8]), розмір посадового окладу асистента чи викладача - 3,64 розміру прожиткового мінімуму для працездатних осіб в Україні у 2021 році. Втім, досі не вщухають дискусії з приводу адекватності встановлених розмірів мінімальної заробітної плати та прожиткового мінімуму. До слова, у попередньому дослідженні [9] було здійснено моніторинг ринкових цін на продукти споживчого кошику та за чинними нормами розраховано реальне значення прожиткового мінімуму, яке виявилося на $38 \%$ більшим за встановлене 282 
державою. Зрозуміло, що талановиті та працьовиті молоді люди (адже саме таким зазвичай пропонується працевлаштування в закладі вищої освіти) не зможуть тривалий час знаходитися на такому рівні оплати праці, адже, окрім задоволення особистісних потреб, будуть мати витрати, пов'язані 3 опублікуванням і апробацією результатів дисертації, захист якої є обов'язковою умовою їх подальшої науковопедагогічної кар'єри.

Тому спостерігається зменшення попиту молоді на працевлаштування в закладах вищої освіти в Україні та відтік молодих фахівців з системи вищої освіти України саме у зв'язку з пропонованим рівнем оплати праці.

\section{Література:}

1. Шевченко I. Ю. Заклади вищої освіти в Україні: проблеми та перспективи розвитку. Pridneprovskiy scientific bulletin. 2018. № 585. T. 23. C. $17-21$.

2. Шевченко І. Ю. Огляд проблем розвитку вищих навчальних закладів в Україні. Економіка. Фінанси. Право. 2017. № 11(2). С. 48-49.

3. Шевченко І. Ю. Кадрове забезпечення системи вищої освіти в Україні: криза чи еволюція? Scientific Collection «InterConf», (38): with the Proceedings of the 1st International Scientific and Practical Conference "Science, Education, Innovation: Topical Issues and Modern Aspects» (December 16-18, 2020). Tallinn, Estonia: Uhingu Teadus juhatus, 2020. P. 455-457.

4. Про вищу освіту: Закон України у редакції від 10 липня 2021 року. URL: https://zakon.rada.gov.ua/laws/show/1556-18

5. Про освіту: Закон України у редакції від 10 липня 2021 року. URL: https://zakon.rada.gov.ua/laws/show/2145-19

6. Оплата праці педпрацівників: посадові оклади 2021 року. URL: https://www.budgetnyk.com.ua/article/467-oplata-prats-pedpratsvnikv-posadov-okladi-2021-roku?from=PW_Time_Auth_Desktop_Budgetny$k \&$ token $=28658268$-bcaa- $11 \mathrm{a} 0-\mathrm{cc} 7 \mathrm{~d}-2 \mathrm{~d} 01 \mathrm{a} 7324 \mathrm{f} 14 \& \mathrm{ttl}=7776000 \&$ ustp $=\mathrm{W}$

7. Мінімальна зарплата в Україні. URL: https:// index.minfin.com.ua/ua/ labour/salary/min/

8. Прожитковий мінімум 2021. URL: https://smartfin.ua/page/prozhyt kovyy-minimum-2021

9. Бережний В. М., Шевченко I. Ю. Обгрунтування сучасного розміру прожиткового мінімуму в Україні. Pridneprovskiy scientific bulletin. 2011. № 245, т. 21. C. 87-93. 